\title{
Piperidine-Substituted Perylene Sensitizer for Dye-Sensitized Solar Cells
}

\author{
Joe Otsuki, ${ }^{1,2}$ Yusho Takaguchi, ${ }^{1}$ Daichi Takahashi, ${ }^{1}$ Palanisamy Kalimuthu, ${ }^{1,3}$ \\ Surya Prakash Singh, ${ }^{4}$ Ashraful Islam, ${ }^{4,5}$ and Liyuan Han ${ }^{4}$
}
${ }^{1}$ Department of Materials and Applied Chemistry, College of Science and Technology, Nihon University, 1-8-14 Kanda Surugadai, Chiyoda-ku, Tokyo 101-8308, Japan
${ }^{2}$ Center for Creative Materials Research, College of Science and Technology, Nihon University, 1-8-14 Kanda Surugadai, Chiyoda-ku, Tokyo 101-8308, Japan
${ }^{3}$ Department of Chemistry, Gandhigram Rural University, Gandhigram, 624302 Dindigul, Tamil Nadu, India
${ }^{4}$ Photovoltaic Materials Unit, National Institute for Materials Science (NIMS), 1-2-1 Sengen, Tsukuba, Ibaraki 305-0047, Japan
${ }^{5}$ Center of Excellence for Research in Engineering Materials (CEREM), College of Engineering, King Saud University, Riyadh 11421, Saudi Arabia

Correspondence should be addressed to Joe Otsuki, otsuki.joe@nihon-u.ac.jp and Ashraful Islam, islam.ashraful@nims.go.jp

Received 30 April 2011; Accepted 31 May 2011

Academic Editor: Ahmed El-Shafei

Copyright $\odot 2011$ Joe Otsuki et al. This is an open access article distributed under the Creative Commons Attribution License, which permits unrestricted use, distribution, and reproduction in any medium, provided the original work is properly cited.

\begin{abstract}
We have prepared a novel piperidine-donor-substituted perylene sensitizer, PK0002, and studied the photovoltaic performance in dye-sensitized solar cells (DSSCs). Physical properties and photovoltaic performance of this new perylene derivative PK0002 are reported and compared with those of unsubstituted perylene sensitizer, PK0003. PK0002, when anchored to nanocrystalline $\mathrm{TiO}_{2}$ films, achieves very efficient sensitization across the whole visible range extending up to $800 \mathrm{~nm}$. The incident photon-tocurrent conversion efficiency (IPCE) spectrum was consistent with the absorption spectrum and resulted in a high short-circuit photocurrent density $\left(J_{\mathrm{sc}}\right)$ of $8.8 \mathrm{~mA} \mathrm{~cm}^{-2}$. PK0002 showed higher IPCE values than PK0003 in the 520-800 nm region. Under standard AM 1.5 irradiation $\left(100 \mathrm{~mW} \mathrm{~cm}^{-2}\right)$ and using an electrolyte consisting of $0.6 \mathrm{M}$ dimethylpropyl-imidazolium iodide, $0.05 \mathrm{M} \mathrm{I}_{2}, 0.1 \mathrm{M} \mathrm{LiI}$, and $0.5 \mathrm{M}$ tert-butylpyridine in acetonitrile, a solar cell containing sensitizer PK0002 yielded a short-circuit photocurrent density of $7.7 \mathrm{~mA} \mathrm{~cm}^{-2}$, an open-circuit photovoltage of $0.57 \mathrm{~V}$, and a fill factor of 0.70 , corresponding to an overall conversion efficiency of $3.1 \%$.
\end{abstract}

\section{Introduction}

Dye-sensitized solar cells (DSSCs) have been widely investigated because of their simple structure and potential for low-cost production [1-3]. In this solar cell, a monolayer of dyes is attached to the surface of nanocrystalline $\mathrm{TiO}_{2}$ film to absorb solar light. The molecular design of dye-sensitizers that can absorb visible light of all colors for nanocrystalline oxide semiconductor solar cells is a challenging task as several requirements have to be fulfilled by the dye which are very difficult to be met simultaneously. Most of current research concerns development of panchromatic sensitizers based on organic dyes and transition metal complexes. Towards this goal, a number of transition metal complexes are used as effective sensitizers, due to their intense charge-transfer absorption over the whole visible range and highly efficient metal-to-ligand charge-transfer in a dye-sensitized solar cell device. DSSCs with dyes based on ruthenium complexes have achieved energy conversion efficiencies over $11 \%[4,5]$. In recent years, there has been much effort in replacing the ruthenium complexes with fully organic photosensitizers for environmental reasons, lower cost, and the possibility to obtain very high extinction coefficients, which could also allow application in thinner solar cells as demanded in, for example, solid-state DSSCs.

Derivatives of perylene have been widely applied in various optical devices owing to their outstanding chemical, thermal, and photochemical stability and nontoxicity [612]. Several perylene dyes have been used as sensitizers 
<smiles></smiles><smiles></smiles>

Figure 1: Perylene derivatives.

in DSSCs, however, they exhibited very low overall power conversion efficiencies [13-16]. Li and Edvinsson reported diphenylamino-substituted perylene monoanhydrides as sensitizers with power conversion efficiency 3.9\% [17], later on they reported $6.8 \%$ power conversion efficiency with new perylene sensitizer bearing two thiophenol groups [18]. As our research program in developing the new sensitizers [19], herein, we present a novel piperidine-donor-substituted perylene sensitizer (PK0002) and compare with unsubstituted perylene sensitizer (PK0003) as shown in Figure 1.

\section{Experimental}

2.1. General. Dehydrated DMF was purchased from Aldrich. The synthesis of PK0003 [20] and compound 1 [20, 21] was performed as reported in the literature. ${ }^{1} \mathrm{H}$ NMR was recorded using a JEOL JNM-ECX-400 spectrometer $(400 \mathrm{MHz})$ and the chemical shifts are referenced to internal tetramethylsilane. Atmospheric pressure chemical ionization (APCI)-HRMS was obtained on an Agilent LC/MSD TOF spectrometer. Absorption and emission spectra were obtained using Shimadzu UV-2400PC and RF-5300PC spectrometers, respectively. Spectroscopic-grade $\mathrm{CHCl}_{3}$ was purchased from Kanto Chemical. DFT calculations were performed with a Gaussian03 package using B3LYP/6-31G.

Synthesis of 2. A mixture of compound 1 ( $100 \mathrm{mg}$, $0.170 \mathrm{mmol})$ and piperidine $(0.30 \mathrm{~mL}, 3.6 \mathrm{mmol})$ in DMF $(10 \mathrm{~mL})$ was refluxed under $\mathrm{N}_{2}$ for $3 \mathrm{~h}$. The reaction mixture turned from bright scarlet to deep blue in color. The solvent was removed on a rotary evaporator. The resulting residue was column chromatographed with silica gel and chloroform, yielding a purple solid (69 mg, 61\%). ${ }^{1} \mathrm{H}$ NMR $\left(\mathrm{CDCl}_{3}\right): \delta(\mathrm{ppm})=8.61(2 \mathrm{H}, \mathrm{m}), 8.47(1 \mathrm{H}, \mathrm{m}), 8.40(2 \mathrm{H}$, $\mathrm{m}), 8.33(1 \mathrm{H}, \mathrm{m}), 8.24(1 \mathrm{H}, \mathrm{d}, J=8.7 \mathrm{~Hz}), 7.64(1 \mathrm{H}, \mathrm{t}, J$ $=8.1 \mathrm{~Hz}), 7.58(1 \mathrm{H}, \mathrm{d}, J=8.7 \mathrm{~Hz}), 7.44(1 \mathrm{H}, \mathrm{dd}, J=8.7$, $2.2 \mathrm{~Hz}), 7.20(1 \mathrm{H}, \mathrm{d}, J=8.3 \mathrm{~Hz}), 7.02(1 \mathrm{H}, \mathrm{d}, J=2.3 \mathrm{~Hz}), 3.19$ $(4 \mathrm{H}, \mathrm{br}), 1.90(4 \mathrm{H}, \mathrm{m}), 1.73(2 \mathrm{H}, \mathrm{br}), 1.33(9 \mathrm{H}, \mathrm{s}), 1.30(9 \mathrm{H}$, s). APCI-HRMS: calcd for $\mathrm{C}_{41} \mathrm{H}_{41} \mathrm{~N}_{2} \mathrm{O}_{2}\left(\mathrm{MH}^{+}\right), 593.3163$; found: 593.3008 .
Synthesis of PK0002. Crushed $\mathrm{KOH}$ pellets $(1.5 \mathrm{~g})$ were added to a suspension of $2(60 \mathrm{mg}, 0.11 \mathrm{mmol})$ in $t$-butanol $(50 \mathrm{~mL})$ and the mixture was vigrously refluxed with stirring for 2 hrs (Scheme 1). The blue solid slowly dissolved and the solution turned yellow. While hot, the reaction mixture was cautiously poured into glacial acetic acid $(100 \mathrm{~mL})$ with vigorous stirring. The deep blue color returned immediately and a solid precipitated. The suspension was cooled and chloroform was added to dissolve the solid. The organic layer was washed 3 times with water, dried over anhydrous sodium sulfate, stripped on a rotary evaporator and dried overnight in a dessicator. The crude product was column chromatographed on silica gel with chloroform, yielding a purple solid $(69 \mathrm{mg}, 45 \%) .{ }^{1} \mathrm{H} \mathrm{NMR}\left(\mathrm{CDCl}_{3}\right): \delta(\mathrm{ppm})=$ $8.24(4 \mathrm{H}, \mathrm{m}), 8.21(1 \mathrm{H}, \mathrm{d}, J=8.2 \mathrm{~Hz}), 8.02(1 \mathrm{H}, \mathrm{d}, J=$ $7.8 \mathrm{~Hz}), 7.92(1 \mathrm{H}, \mathrm{d}, J=8.2 \mathrm{~Hz}), 7.56(1 \mathrm{H}, \mathrm{t}, J=7.8 \mathrm{~Hz}), 7.08$ $(1 \mathrm{H}, \mathrm{d}, J=8.2 \mathrm{~Hz}), 3.21(4 \mathrm{H}, \mathrm{br}), 1.91(4 \mathrm{H}, \mathrm{m}), 1.74(2 \mathrm{H}$, m). APCI-HRMS: calcd for $\mathrm{C}_{27} \mathrm{H}_{20} \mathrm{NO}_{3}\left(\mathrm{MH}^{+}\right), 406.1438$; found: 406.1342 .

2.2. Fabrication of Dye-Sensitized Solar Cell. A nanocrystalline $\mathrm{TiO}_{2}$ photoelectrodes of $20 \mu \mathrm{m}$ thickness (area: $0.25 \mathrm{~cm}^{2}$ ) was prepared by screen-printing on conducting glass as previously described [22]. The films were further treated with $0.05 \mathrm{M} \mathrm{TiCl}_{4}$ and $0.1 \mathrm{M} \mathrm{HCl}$ aqueous solutions before examination [23]. Coating of the $\mathrm{TiO}_{2}$ film was carried out by immersing for $20 \mathrm{~h}$ in a sensitizer solution of $3 \times$ $10^{-4} \mathrm{M}$ dichlorobezene solution. Deoxycholic acid $(20 \mathrm{mM})$ was added to the dye solution as a coadsorbent to prevent aggregation of the dye molecules $[24,25]$. Photovoltaic measurements were performed in a two-electrode sandwich cell configuration. The dye-deposited $\mathrm{TiO}_{2}$ film and a platinum-coated conducting glass were used as the working electrode and the counter electrode, respectively. The two electrodes were separated by a surlyn spacer ( $40 \mu \mathrm{m}$ thick) and sealed by heating the polymer frame. The electrolytes were composed of $0.6 \mathrm{M}$ dimethylpropyl-imidazolium iodide (DMPII), $0.05 \mathrm{M} \mathrm{I}_{2}$, and $0.1 \mathrm{M} \mathrm{LiI}$ in acetonitrile with $(0.5 \mathrm{M})$ or without tert-butylpyridine (TBP).

2.3. Photovoltaic Characterization. The working electrode was illuminated through a conducting glass. The currentvoltage characteristics were measured using a solar simulator (AM-1.5, $100 \mathrm{~mW} / \mathrm{cm}^{2}$, WXS-155S-10: Wacom Denso Co. Japan). Monochromatic incident photon-to-current conversion efficiency (IPCE) for the solar cell, plotted as a function of excitation wavelength, was recorded on a CEP-2000 system (Bunkoh-Keiki Co. Ltd.). Incident photonto-current conversion efficiency (IPCE) at each incident wavelength was calculated from (1), where $I_{\mathrm{sc}}$ is the photocurrent density at short circuit in $\mathrm{mA} \mathrm{cm}^{-2}$ under monochromatic irradiation, $\lambda$ is the wavelength of incident radiation in $\mathrm{nm}$, and $\phi$ is the incident radiative flux in $\mathrm{mW} \mathrm{cm}{ }^{-2}$

$$
\operatorname{IPCE}(\lambda)=1240\left(\frac{I_{\mathrm{SC}}}{\lambda \phi}\right) .
$$



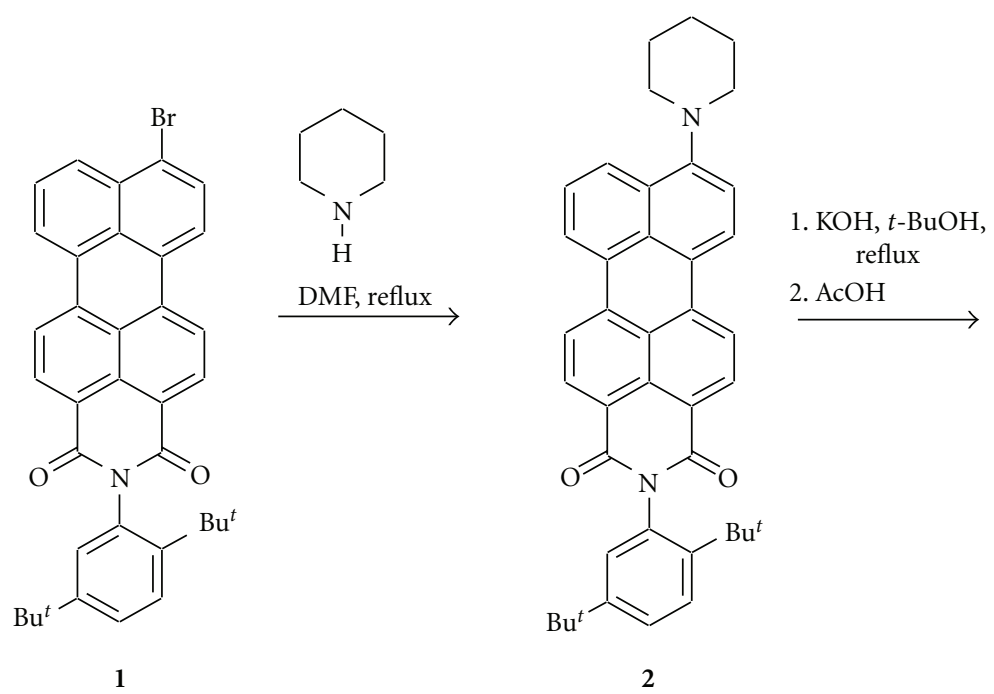<smiles>O=C1OC(=O)c2ccc3c4ccc(N5CCCCC5)c5cccc(c6ccc1c2c63)c54</smiles>

Scheme 1: Preparation of PK0002.

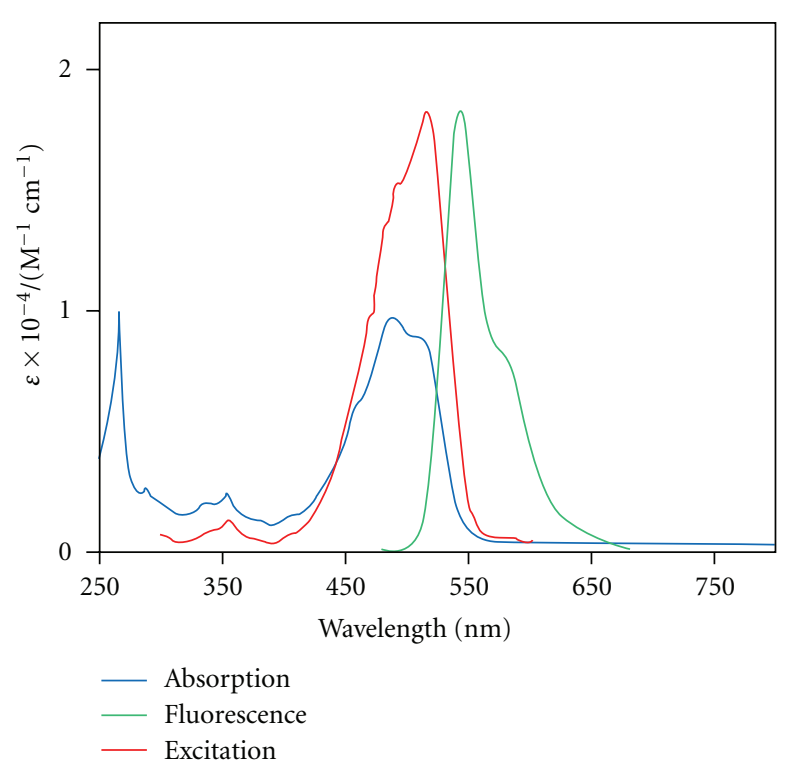

(a)

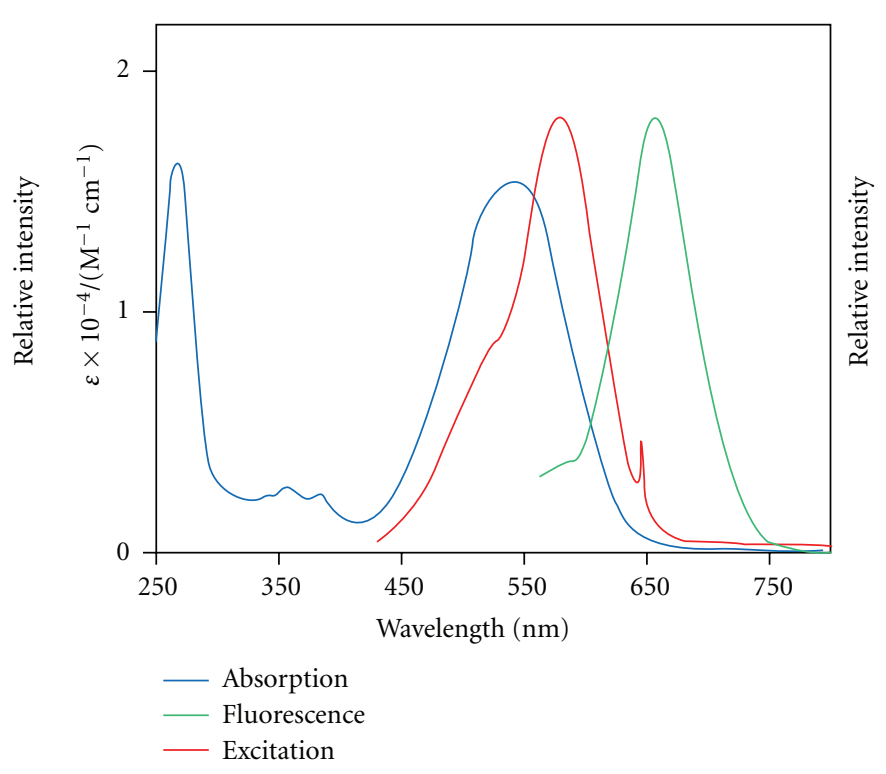

(b)

Figure 2: Absorption, fluorescence, and excitation spectra of PK0003 (a) and PK0002 (b) in $\mathrm{CHCl}_{3}$.

\section{Results and Discussion}

3.1. Photophysical Properties. The absorption, excitation, and fluorescence spectra for PK0003 and PK0002 are shown in Figure 2, and the numerical data are summarized in Table 1. The absorption maxima $\left(\lambda_{\max }\right)$ of PK0003 and PK0002 were observed at $489 \mathrm{~nm}$ and $544 \mathrm{~nm}$, respectively. Their molar absorption coefficients $(\varepsilon)$ were calculated to be $1.0-1.6 \times 10^{4} \mathrm{M}^{-1} \mathrm{~cm}^{-1}$. The fluorescence emission maxima $\left(\lambda_{\text {flur }}\right)$ of PK0003 and PK0002 were observed at $543 \mathrm{~nm}$ and $655 \mathrm{~nm}$, respectively. It is noticed that on going from PK0003 without a donor group to PK0002 with the donor group, the structured absorption and fluorescence bands become broader and are shifted to longer wavelengths, and the Stokes shift becomes larger. These observations imply that the more charge-transfer character is involved in the $\pi$ $\pi^{*}$ transition of the donor-substituted PK0002. PK0003 and PK0002 show a blue-shifted absorption when adsorbed onto $\mathrm{TiO}_{2}$ (Figure 3). This effect is attributed to the ring opening of the anhydride group on perylene to form two carboxylates, providing interactions with the oxide surface.

To obtain an insight into the electron distribution and relative energy level of PK0003 and PK0002 for better understanding of the charge injection and dye regeneration process, the highest occupied molecular orbital (HOMO) and the lowest unoccupied molecular orbital (LUMO) of PK0003 and PK0002 were calculated with B3LYP/6-31G implemented in a Gaussian-03 program package (Figure 4). 
TAble 1: Physical properties of PK0003 and PK0002.

\begin{tabular}{|c|c|c|c|c|c|c|c|c|}
\hline \multirow{2}{*}{ Compound } & \multicolumn{2}{|c|}{ Absorption $^{(a)}$} & \multicolumn{2}{|c|}{ Fluorescence $^{(\mathrm{a})}$} & \multirow{2}{*}{$\begin{array}{c}\text { Absorption on } \mathrm{TiO}_{2} \text { film } \\
\lambda_{\max } / \mathrm{nm}\end{array}$} & \multirow{2}{*}{$\begin{array}{c}\mathrm{IP} \\
(\mathrm{eV})\end{array}$} & \multirow{2}{*}{$\begin{array}{c}E^{0-0(\mathrm{c})} \\
(\mathrm{eV})\end{array}$} & \multirow{2}{*}{$\begin{array}{l}\mathrm{LUMO}^{(\mathrm{d})} \\
(\mathrm{eV})\end{array}$} \\
\hline & $\lambda_{\max } / \mathrm{nm}$ & $\varepsilon \times 10^{-4} / \mathrm{M}^{-1} \mathrm{~cm}^{-1}$ & $\lambda_{\mathrm{ex}} / \mathrm{nm}^{(\mathrm{b})}$ & $\lambda_{\text {fluor }} / \mathrm{nm}^{(\mathrm{b})}$ & & & & \\
\hline РК0003 & 489 & 1.0 & 516 & 543 & 450 & -5.88 & 2.07 & -3.81 \\
\hline PK0002 & 544 & 1.6 & 580 & 655 & 500 & -5.60 & 1.77 & -3.83 \\
\hline
\end{tabular}

(a) $\mathrm{In}_{\mathrm{CHCl}}$.

(b) At emission maximum.

${ }^{(c)} E^{0-0}$ values were estimated from the $5 \%$ intensity level of the absorption spectra on $\mathrm{TiO}_{2}$.

${ }^{(\mathrm{d})}$ Calculated from $E^{*}(\mathrm{LUMO})=E(\mathrm{IP})-E^{0-0}$.

Table 2: The photovoltaic data of DSSCs based on PK0003 and PK0002.

\begin{tabular}{|c|c|c|c|c|c|}
\hline Dye & TBP & $J_{\mathrm{sc}}\left[\mathrm{mA} \mathrm{cm}^{-2}\right]$ & $V_{\mathrm{oc}}[\mathrm{V}]$ & F.F. & Eff. [\%] \\
\hline PK0003 & 0 & 7.6 & 0.45 & 0.63 & 2.2 \\
\hline PK0003 & $0.5 \mathrm{M}$ & 4.1 & 0.56 & 0.69 & 1.6 \\
\hline PK0002 & 0 & 8.8 & 0.41 & 0.59 & 2.1 \\
\hline PK0002 & $0.5 \mathrm{M}$ & 7.7 & 0.57 & 0.70 & 3.1 \\
\hline
\end{tabular}

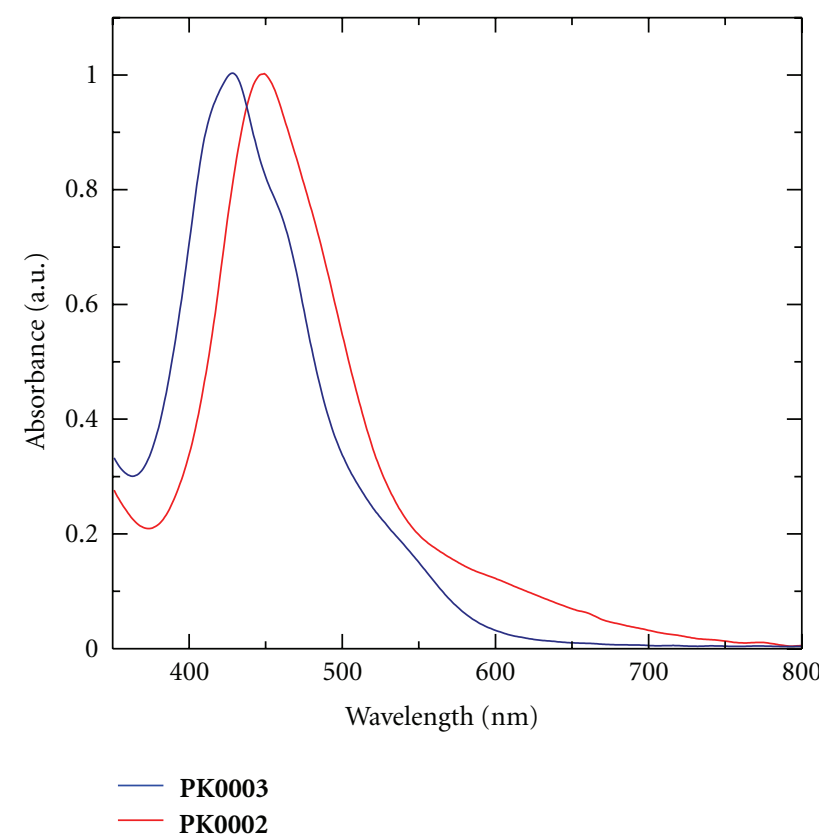

Figure 3: Absorption spectra of PK0003- and PK0002-adsorbed $\mathrm{TiO}_{2}$ film.

The HOMO and LUMO energies are $-5.88 \mathrm{eV}$ and $-3.18 \mathrm{eV}$, respectively, for PK0003. The corresponding energies for PK0002 are $-5.31 \mathrm{eV}$ and $-2.88 \mathrm{eV}$, respectively. These values are positively shifted due to the introduction of the donor moiety, piperidine, at the 9th position. The influence of the introduction of the donor group is larger on the HOMO, which is shifted by $+0.57 \mathrm{eV}$, than on the LUMO, which is shifted by $+0.30 \mathrm{eV}$. Upon adsorption on the $\mathrm{TiO}_{2}$ surface, the carboxylic anhydride group is believed to be cleaved to become dicarboxylate. Therefore, the DFT calculations were also conducted for disodium salts of the dicarboxylate as models for the adsorbed molecules. The HOMO and LUMO energies for PK0002 are $-4.33 \mathrm{eV}$ and $-1.63 \mathrm{eV}$, respectively [20]. The major effect is rise in energy of both of the HOMO and LUMO. The effect is more pronounced for the LUMO, resulting in an increase in the HOMO-LUMO gap from $2.43 \mathrm{eV}$ for the anhydride to $2.70 \mathrm{eV}$ for the dicarboxylate. This result agrees with the blue-shifted absorption spectra of PK0003 and PK0002 when adsorbed onto $\mathrm{TiO}_{2}$ (Figure 3).

The ionization potential (IP) of PK0003 and PK0002 bound to nanocrystalline $\mathrm{TiO}_{2}$ film was determined using a photoemission yield spectrometer (Riken Keiki AC-3E). The ground-state oxidation potential (IP) values of $-5.88 \mathrm{eV}$ and $-5.60 \mathrm{eV}$ obtained for sensitizer PK0003 and PK0002, respectively, were low enough for efficient regeneration of the oxidized dye through reaction with iodide [26]. The excitedstate oxidation potential, LUMO, of sensitizers PK0003 and PK0002 was estimated at $-3.81 \mathrm{eV}$ and $-3.83 \mathrm{eV}$, respectively, which lies above the conduction band edge $(-4.2 \mathrm{eV})$ [2] of nanocrystalline $\mathrm{TiO}_{2}$. Efficient electron injection into the conduction band of $\mathrm{TiO}_{2}$ is therefore expected to occur with both sensitizers PK0003 and PK0002.

3.2. Photovoltaic Performance. The photovoltaic properties of the solar cells fabricated with these organic dyes were measured under simulated AM 1.5G irradiation $\left(100 \mathrm{~mW} \mathrm{~cm}^{-2}\right)$. The open-circuit photovoltage $\left(V_{\mathrm{oc}}\right)$, short-circuit photocurrent density $\left(J_{\mathrm{sc}}\right)$, fill factor (ff), and solar energy-toelectricity conversion efficiencies $(\eta)$ were listed in Table 2. Figure 5 shows the photocurrent action spectra for the cells with sensitizers PK0003 and PK0002 where the incident photons-to-current conversion efficiency (IPCE) values are plotted as a function of wavelength. PK0003 achieved efficient sensitization of nanocrystalline $\mathrm{TiO}_{2}$ across the whole visible range and displayed the highest IPCE value of $80 \%$ at around $450 \mathrm{~nm}$. Under similar conditions, PK0002 showed higher IPCE values than PK0003 in the 520-800 nm region. This result is consistent with the absorption spectra of the sensitizers on the $\mathrm{TiO}_{2}$ surface (Figure 3). PK0002 shows the highest IPCE value of $70 \%$ at around $470 \mathrm{~nm}$. One possible explanation for this low IPCE value of sensitizer PK0002 is the aggregation of sensitizer molecules on the 

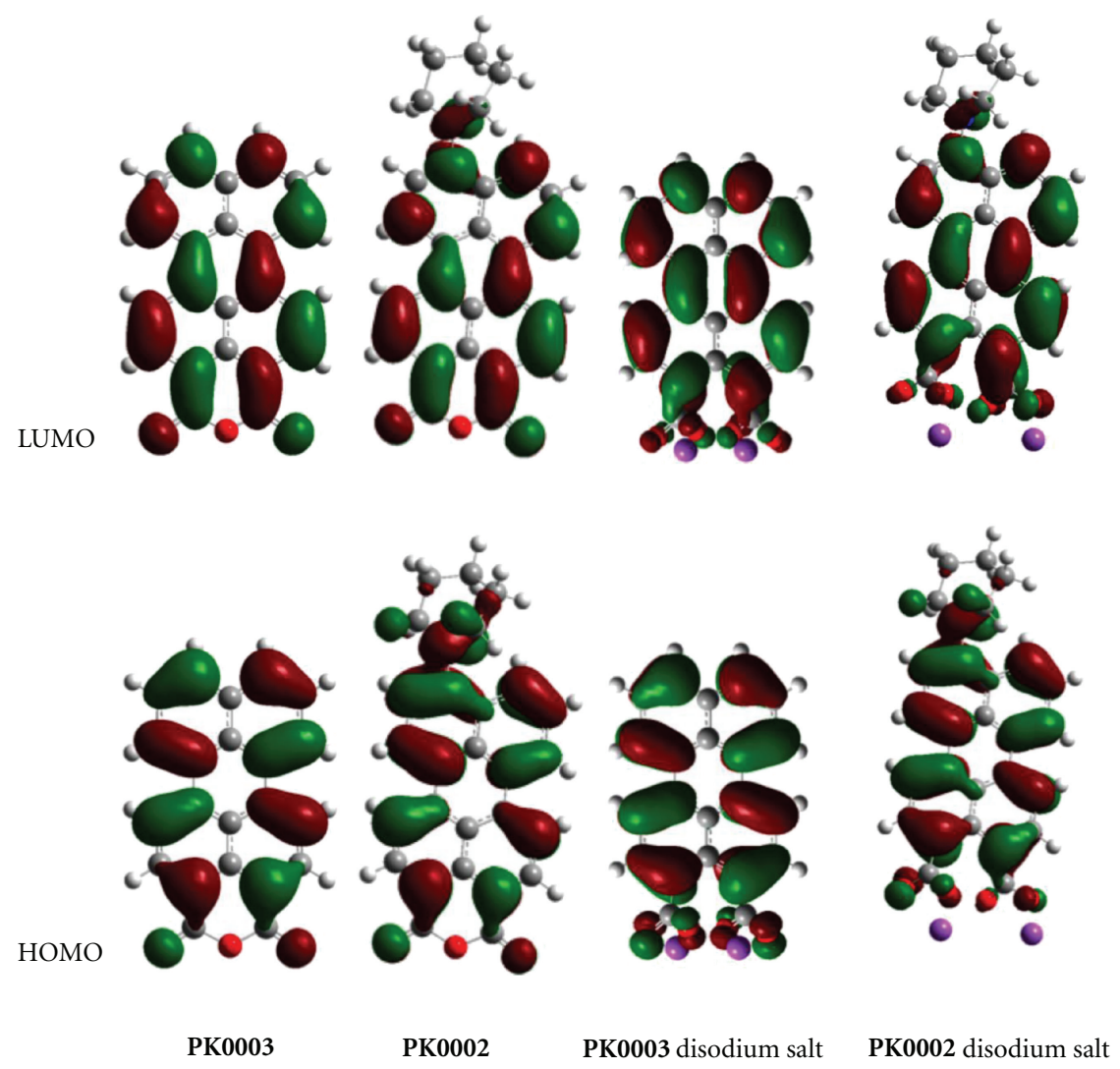

Figure 4: Frontier orbitals of PK0003 and PK0002.

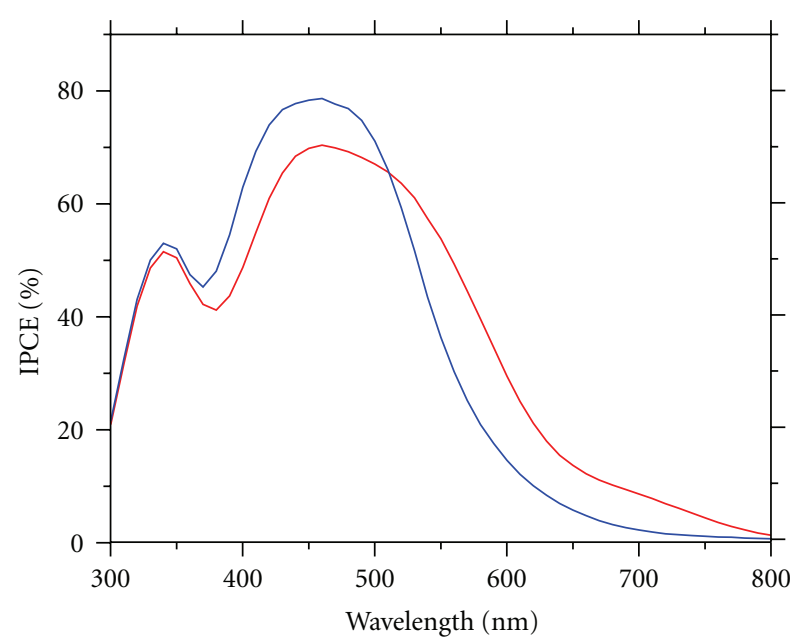

PK0003
- PK0002

Figure 5: Photocurrent action spectra (IPCE) of nanocrystalline $\mathrm{TiO}_{2}$ film sensitized by PK0003 (blue line) and PK0002 (red line). The redox electrolyte solution was a mixture of $0.6 \mathrm{M} \mathrm{DMPII}$, $0.05 \mathrm{M} \mathrm{I}_{2}$, and $0.1 \mathrm{M} \mathrm{LiI}$ in acetonitrile.

$\mathrm{TiO}_{2}$ surface, which could not be completely suppressed by addition of deoxycholic acid (DCA) as a coadsorbent.

Figure 6 shows photocurrent voltage curves of a sandwich-type sealed solar cell based on PK0003 and

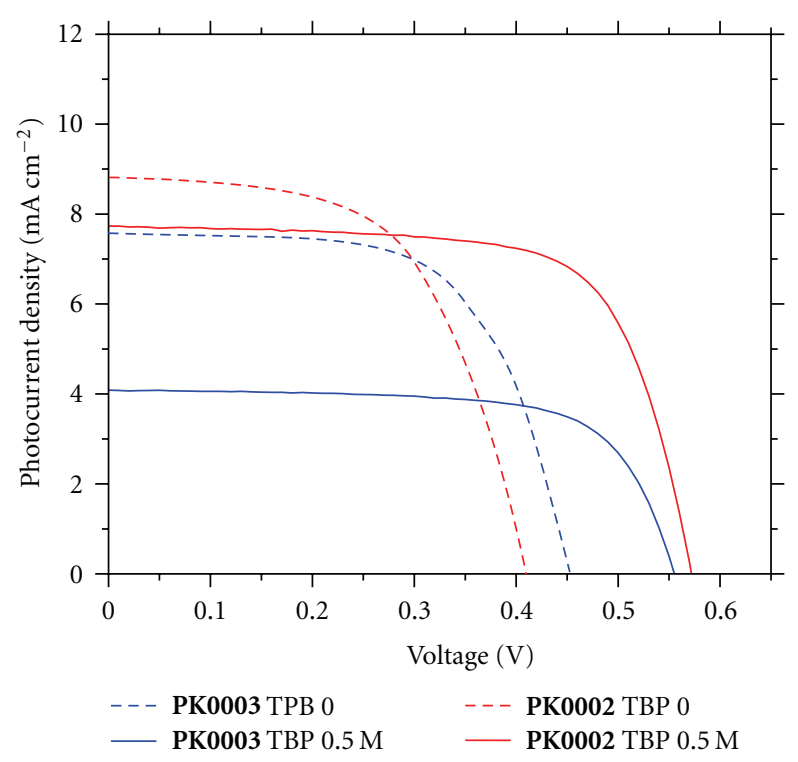

FIGURE 6: Photocurrent voltage characteristics of a nanocrystalline photoelectrochemical cell sensitized with the dye PK0003 and PK0002 at AM 1.5 illuminations (light intensity: $100 \mathrm{~mW} \mathrm{~cm}^{-2}$ ).

PK0002 at standard AM 1.5 irradiation with using an electrolyte of $0.6 \mathrm{M}$ dimethylpropyl-imidazolium iodide (DMPII), $0.05 \mathrm{M} \mathrm{I}_{2}$ and $0.1 \mathrm{M} \mathrm{LiI} \mathrm{in} \mathrm{acetonitrile} \mathrm{with}$ $(0.5 \mathrm{M})$ or without tert-butylpyridine (TBP). PK0003 and 
PK0002-sensitized cell gave a short-circuit photocurrent density $\left(J_{\mathrm{sc}}\right)$ of $7.6 \mathrm{~mA} \mathrm{~cm}^{-2}$ and $8.8 \mathrm{~mA} \mathrm{~cm}^{-2}$, and an overall conversion efficiency $(\eta)$ of $2.2 \%$ and $2.1 \%$, respectively, using electrolytes with no TBP. The short-circuit photocurrent density decreased by adding TBP in the electrolyte. In contrast, the open-circuit voltage and the fill factor increased significantly with the presence of TBP. TBP probably adsorbed on the bare $\mathrm{TiO}_{2}$ surface and suppress the recombination between the injected electrons and $\mathrm{I}_{3}{ }^{-}$ ions [27]. As shown in Table 2, the solar cell sensitized with PK0002 showed a photocurrent density of $7.7 \mathrm{~mA} \mathrm{~cm}^{-2}$, an open-circuit potential of $0.57 \mathrm{~V}$, and a fill factor of 0.70 , corresponding to an overall conversion efficiency $(\eta)$ of $3.1 \%$ with the electrolyte containing $0.5 \mathrm{M}$ TBP under standard AM 1.5 irradiation $\left(100 \mathrm{~mW} \mathrm{~cm}^{-2}\right)$. Thus, this class of piperidine-substituted perylene sensitizer serves as a basis for further design of new potential sensitizers by introducing suitable substituents on the perylene to improve the light harvesting efficiency of the sensitizer.

\section{Conclusion}

We have synthesized a novel perylene derivative with a piperidine donor substituent, PK0002, for dye-sensitized solar cells. PK0002 achieved very efficient sensitization of nanocrystalline $\mathrm{TiO}_{2}$ over the whole visible range extending into the near-IR region (ca. $800 \mathrm{~nm}$ ). The photovoltaic data of this new sensitizer show 3.1\% power conversion efficiency under standard AM 1.5 irradiation $\left(100 \mathrm{~mW} \mathrm{~cm}^{-2}\right)$. Further study will target the development of a high-performance solar cell through modification of the electronic and steric environments of the sensitizers on the basis of alteration of the substituent on the perylene moiety.

\section{Acknowledgments}

This work was partially supported by the Nihon University Strategic Research Project "Nanotechnology Excellence" and Grant-in-Aid for Scientific Research, no. 22108532 (Innovative Areas "Coordination Programming" Area 2107) from the Ministry of Education, Culture, Sports, Science and Technology, Japan.

\section{References}

[1] B. O’Regan and M. Grätzel, "A low-cost, high-efficiency solar cell based on dye-sensitized colloidal $\mathrm{TiO}_{2}$ films," Nature, vol. 353, no. 6346, pp. 737-740, 1991.

[2] A. Hagfeld and M. Grätzel, "Light-induced redox reactions in nanocrystalline systems," Chemical Reviews, vol. 95, no. 1, pp. 49-68, 1995.

[3] A. Hagfeld and M. Grätzel, "Molecular photovoltaics," Accounts of Chemical Research, vol. 33, no. 5, pp. 269-277, 2000.

[4] Y. Chiba, A. Islam, Y. Watanabe, R. Komiya, N. Koide, and L. Han, "Dye-sensitized solar cells with conversion efficiency of 11.1\%," Japanese Journal of Applied Physics, Part 2, vol. 45, no. 24-28, pp. L638-L640, 2006.
[5] Q. Wang, S. Ito, M. Grätzel et al., "Characteristics of high efficiency dye-sensitized solar cells," Journal of Physical Chemistry B, vol. 110, no. 50, pp. 25210-25221, 2006.

[6] J. Jacob, S. Sax, T. Piok, E. J. W. List, A. C. Grimsdale, and K. Múllen, "Ladder-type pentaphenylenes and their polymers: efficient blue-light emitters and electron-accepting materials via a commmon intermediate," Journal of the American Chemical Society, vol. 126, no. 22, pp. 6987-6995, 2004.

[7] B. A. Jones, M. J. Ahrens, M. H. Yoon, A. Facchetti, T. J. Marks, and M. R. Wasielewski, "High-mobility airstable n-type semiconductors with processing versatility: dicyanoperylene-3,4:9,10-bis(dicarboximides)," Angewandte Chemie-International Edition, vol. 43, no. 46, pp. 6363-6366, 2004.

[8] V. Lemaur, M. Steel, D. Beljonne, J. L. Brédas, and J. Cornil, "Photoinduced charge generation and recombination dynamics in model donor/acceptor pairs for organic solar cell applications: a full quantum-chemical treatment," Journal of the American Chemical Society, vol. 127, no. 16, pp. 6077-6086, 2005.

[9] E. E. Neuteboom, S. C. J. Meskers, P. A. Van Hal et al., "Alternating oligo(p-phenylene vinylene)-perylene bisimide copolymers: synthesis, photophysics, and photovoltaic properties of a new class of donor-acceptor materials," Journal of the American Chemical Society, vol. 125, no. 28, pp. 8625-8638, 2003.

[10] L. Schmidt-Mende, A. Fechtenkötter, K. Müllen, E. Moons, R. H. Friend, and J. D. MacKenzie, "Self-organized discotic liquid crystals for high-efficiency organic photovoltaics," Science, vol. 293, no. 5532, pp. 1119-1122, 2001.

[11] F. Würthner, Z. Chen, F. J. M. Hoeben et al., "Supramolecular p-n-heterojunctions by co-self-organization of oligo(pphenylene vinylene) and perylene bisimide dyes," Journal of the American Chemical Society, vol. 126, no. 34, pp. 1061110618, 2004.

[12] X. Zhan, Z. Tan, B. Domercq et al., "A high-mobility electrontransport polymer with broad absorption and its use in fieldeffect transistors and all-polymer solar cells," Journal of the American Chemical Society, vol. 129, no. 23, pp. 7246-7247, 2007.

[13] S. Ferrere and B. A. Gregg, "New perylenes for dye sensitization of $\mathrm{TiO}_{2}$," New Journal of Chemistry, vol. 26, no. 9, pp. 1155-1160, 2002.

[14] Y. Shibano, T. Umeyama, Y. Matano, and H. Imahori, "Electron-donating perylene tetracarboxylic acids for dyesensitized solar cells," Organic Letters, vol. 9, no. 10, pp. 19711974, 2007.

[15] T. Dentani, K. Funabiki, J. Y. Jin, T. Yoshida, H. Minoura, and M. Matsui, "Application of 9-substituted 3,4perylenedicarboxylic anhydrides as sensitizers for zinc oxide solar cell," Dyes and Pigments, vol. 72, no. 3, pp. 303-307, 2007.

[16] C. Zafer, M. Kus, G. Turkmen et al., "New perylene derivative dyes for dye-sensitized solar cells," Solar Energy Materials and Solar Cells, vol. 91, no. 5, pp. 427-431, 2007.

[17] T. Edvinsson, C. Li, N. Pschirer et al., "Intramolecular charge-transfer tuning of perylenes: spectroscopic features and performance in dye-sensitized solar cells," Journal of Physical Chemistry C, vol. 111, no. 42, pp. 15137-15140, 2007.

[18] C. Li, J. H. Yum, S. J. Moon et al., "An improved perylene sensitizer for solar cell applications," ChemSusChem, vol. 1, no. 7, pp. 615-618, 2008.

[19] A. Islam, S. P. Singh, M. Yanagida, M. R. Karim, and L. Han, "Amphiphilic ruthenium(II) terpyridine sensitizers with long 
alkyl chain substituted $\beta$-diketonato ligands : an efficient coadsorbent free dye-sensitized solar cells," International Journal of Photoenergy, vol. 2011, Article ID 757421, 7 pages, 2011.

[20] T. Dentani, K. Funabiki, J. Y. Jin, T. Yoshida, H. Minoura, and M. Matsui, "Application of 9-substituted 3,4perylenedicarboxylic anhydrides as sensitizers for zinc oxide solar cell," Dyes and Pigments, vol. 72, no. 3, pp. 303-307, 2007.

[21] L. Feiler, H. Langhals, and K. Polborn, "Synthesis of perylene-3,4-dicarboximides-novel, highly photostable fluorescent dyes," Liebigs Annalen, vol. 1995, no. 7, pp. 1229-1244, 1995.

[22] M. K. Nazeeruddin, P. Péchy, T. Renouard et al., "Engineering of efficient panchromatic sensitizers for nanocrystalline $\mathrm{TiO}_{2}-$ based solar cells," Journal of the American Chemical Society, vol. 123, no. 8, pp. 1613-1624, 2001.

[23] Z. S. Wang, T. Yamaguchi, H. Sugihara, and H. Arakawa, "Significant efficiency improvement of the black dye-sensitized solar cell through protonation of $\mathrm{TiO}_{2}$ films," Langmuir, vol. 21, no. 10, pp. 4272-4276, 2005.

[24] M. Ikeda, N. Koide, L. Han, A. Sasahara, and H. Onishi, "Scanning tunneling microscopy study of black dye and deoxycholic acid adsorbed on a rutile $\mathrm{TiO}_{2}(110)$," Langmuir, vol. 24, no. 15, pp. 8056-8060, 2008.

[25] Z. S. Wang, Y. Cui, Y. Dan-oh, C. Kasada, A. Shinpo, and K. Hara, "Thiophene-functionalized coumarin dye for efficient dye-sensitized solar cells: electron lifetime improved by coadsorption of deoxycholic acid," Journal of Physical Chemistry C, vol. 111, no. 19, pp. 7224-7230, 2007.

[26] G. Oskam, B. V. Bergeron, G. J. Meyer, and P. C. Searson, "Pseudohalogens for dye-sensitized $\mathrm{TiO}_{2}$ photoelectrochemical cells," Journal of Physical Chemistry B, vol. 105, no. 29, pp. 6867-6873, 2001.

[27] K. Hara, Y. Dan-Oh, C. Kasada et al., "Effect of additives on the photovoltaic performance of coumarin-dye- sensitized nanocrystalline $\mathrm{TiO}_{2}$ solar cells," Langmuir, vol. 20, no. 10, pp. 4205-4210, 2004. 

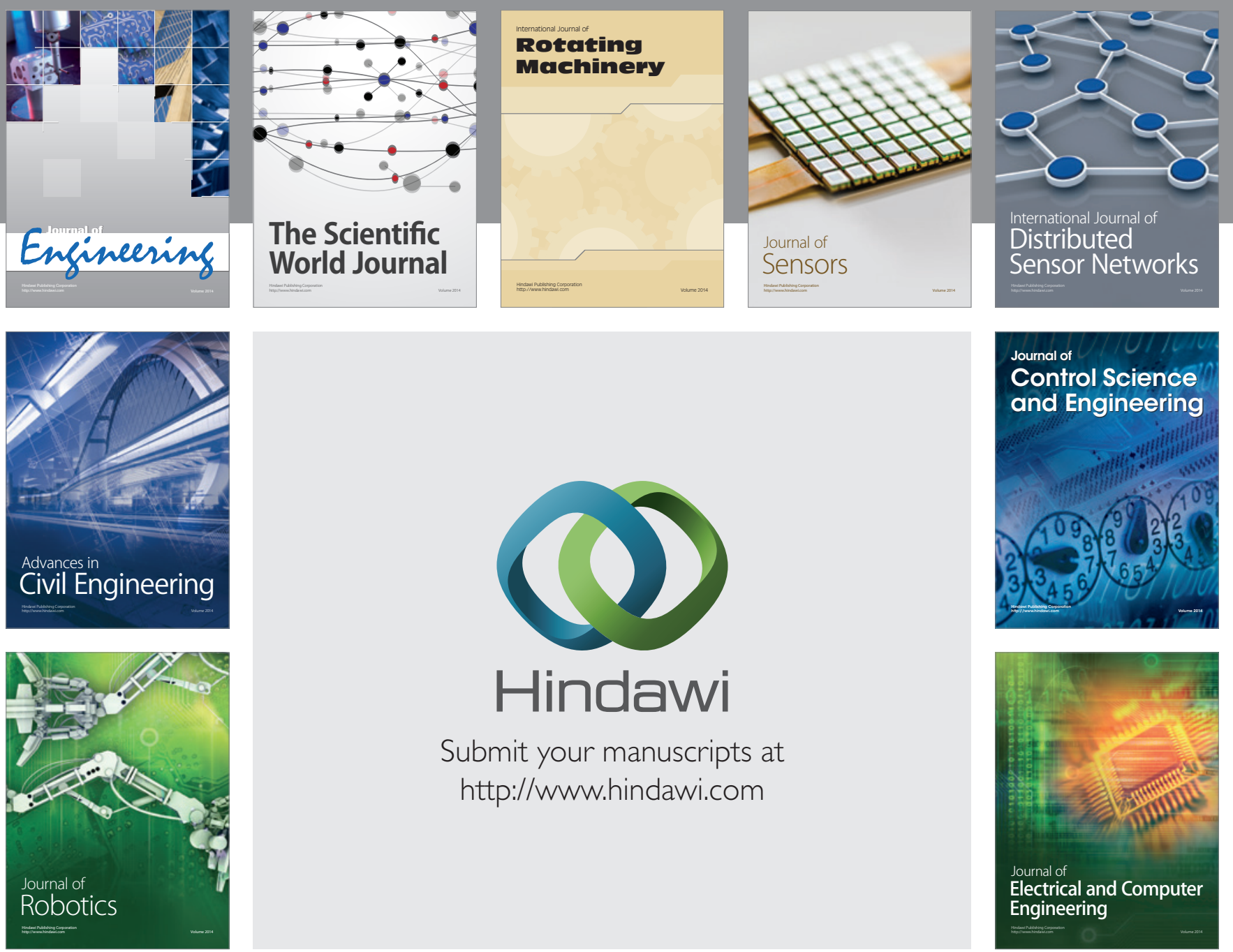

Submit your manuscripts at

http://www.hindawi.com
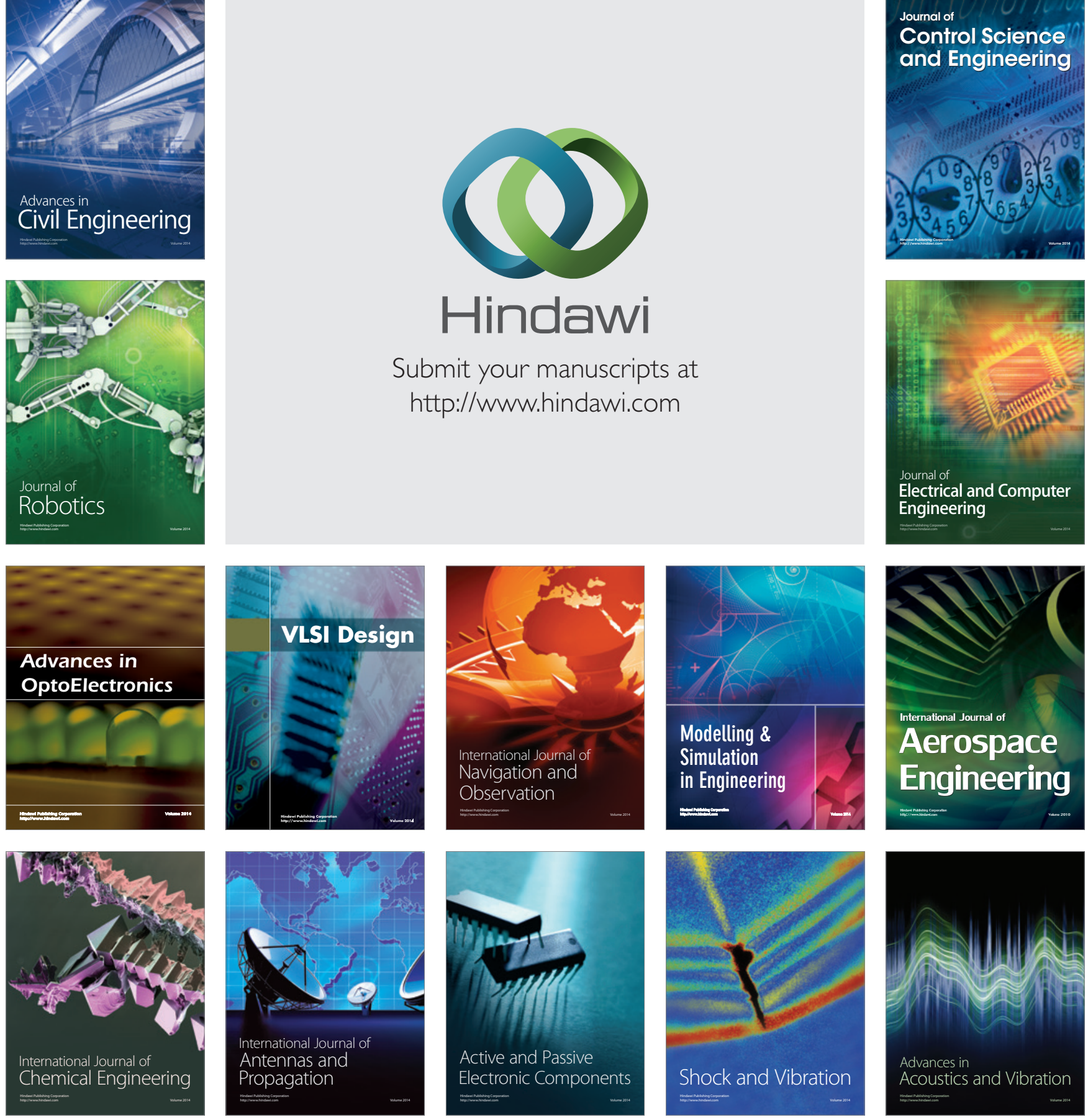